\title{
慢性透析患者に対する冠動脈再建術の経験
}

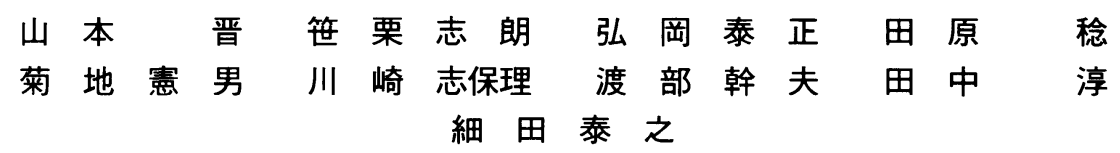

\begin{abstract}
慢性透析患者に対する冠動脈再建術において，体外循環中の血液濾過法（以下 HF）により，血液希釈 率と電解質の管理を試みた. 対象は 1988 年 1 月より 1989 年 12 月までの間に当科で施行した慢性透析 患者に対する冠動脈再建術 7 例であり, 症例の平均年齢は 53 歳, 性別はすべて男性であった. 慢性腎 不全に対しては全例で術前より血液透析（以下 HD）を施行していたがこのうちの 1 例は入院後, さら に持続的腹膜透析（以下 CAPD）を施行し，HD との併用によって管理した。術中は体外循環回路に ダイアライザーを組み込み, 回路内輸血（1，270土372 ml）および大量の輸液 $(12,657 \pm 3,966 \mathrm{ml})$ と 限外濾過による除水 $(18,300 \pm 5,628 \mathrm{ml})$ によって電解質および血液希釈率の調整を行った。術後は第 3 病日までの間に全例で 2 回以上の HD を施行した. 1 例で術後低 K 血症を認めたほかは手術中およ び手術当日の電解質は適正に保たれ，周術期の大きな血行動態の変化はみられなかった．体外循環中 の HF は, 術中 HD と比較してより簡便であり, 短時間で施行できる点からも慢性透析患者における 心臟手術に安全かつ有用な方法と考える。日心外会誌23 巻 1 号 : 1-5 (1994)
\end{abstract}

Keywords : CABG, 血液透析, 血液滤過法, 限外滤過, 体外循環

\section{Coronary Artery Revascularization in Chronic Hemodialysis Patients}

Shin Yamamoto, Shirou Sasaguri, Yasumasa Hirooka, Minoru Tahara, Norio Kikuti, Shiori Kawasaki, Mikio Watanabe, Atsushi Tanaka and Yasuyuki Hosoda (Department of Cardiothoracic Surgery, Juntendo University School of Medicine, Tokyo, Japan)

We controlled the hemodilution and electrolyte levels during coronary artery revascularization in chronic hemodialysis patients by hemofiltration during the period of extracorporeal circulation. Subjects comprised 7 chronic hemodialysis patients (males, average age 53) undergoing coronary artery revascularization in our department from January 1988 to December 1989. All patients had been undergoing hemodialysis for chronic renal failure and in one patient, after admission, continuous ambulatory peritoneal dialysis (CAPD) was additionally performed. During surgery, the dialyzer was equipped with an extracorporeal circulation circuit and the electrolyte level and hemodilution were adjusted using transfusion $(1,270 \pm 372 \mathrm{ml})$. A large infusion volume $(12,657 \pm$ $3,966 \mathrm{ml}$ ) was maintained and removal of water was carried out by ultrafiltration. After surgery, all patients underwent hemodialysis twice or more by the 3rd day of recovery. Concentrations of electrolytes were maintained at appropriate levels throughout the day of surgery except for one case of postoperative hypokalemia, but no marked changes in hemodynamics were observed during and after surgery. Hemofiltration during extracorporeal circulation is safe and useful in coronary surgery because it is simpler and requires less time than hemodialysis. Jpn. J. Cardiovasc. Surg. 23 : 1-5 (1994)

慢性透析患者に対する冠動脈再建術は近年増加 傾向にあり，手術適応も拡大している．術中およ び術後の血液浄化法は現在のところ各施設におい て種々に工夫されている．われわれは術中体外循 環回路にダイアライザーを組み込み HF を行う

1992 年 10 月 30 日受付, 1993 年 4 月 30 日採用

順天堂大学胸部外科 $=113$ 東京都文京区本郷 3-1-3
ことにより，周術期の水分および電解質の管理を 試みたので報告する。

\section{対象と方法}

1988 年 1 月より 1989 年 12 月までの 2 年間に 当科で行った冠動脈再建術 284 例のうち慢性透析 患者に対するものは 7 例 (2.5\%) であった。年齢 
は 48 歳から 58 歳, 平均年齢は $52 \pm 4$ 歳 (mean土 $\mathrm{SD})$, 平均体重 $64 \pm 7 \mathrm{~kg}$ であり全例男性であっ た。

術前状態は陳旧性心筋梗塞を既往とするものが 1 例, 安定狭心症 3 例, 不安定狭心症 4 例であり, 左室駆出率の平均は $69 \pm 11 \%$ であった. 冠動脈危 険因子は高血圧 5 例, 糖尿病 2 例, 高脂血症 7 例, 契煙 4 例, 肥満 3 例であった.HDに至った慢性腎 不全の原因は腎炎が 4 例, 糖尿病性腎症 2 例, 悪 性高血圧によるものが 1 例であり HD の期間は 平均 $7.1 \pm 3.3$ 年であった。血液浄化法は全例が HDであった。

入院後は 6 例で週 3 回の通常どおりの HDを 行い, 1 例は入院後より CAPDを導入し HD に 代えて管理した。手術直前の透析の管理は 5 例が 術前 4 日間で 3 回の HD を行い, 2 例が術前 3 日 間で 2 回の HD を行った。体外循環には膜型肺 （テルモ社製 Capiox E, Havey 社製 HF-5400 な ぞ）を使用し, 非拍動流, 灌流指数 $2.2 \mathrm{l} / \mathrm{min}$, 灌 流圧 60〜90 mmHg で行った。充填液にはカリウ

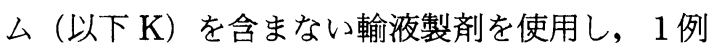
で無血充填を行った。体外循環中は血流希釈およ び電解質の管理,さらに uremic toxin の洗出しを 目的に，生理食塩水とマンニトールおよび $25 \%$ ア ルブミン製剤の混合液を補充液として用い，人工 心肺回路内に組み込んだ 2 基のダイアライザーに よって HF（流量 $200 \mathrm{ml} / \mathrm{min}$, 限外濾過圧 150〜200 mmHg) を行った。このダイアライザー
は oxygenator と reservoir の間に 2 基を並列に おき，濾過効率の増加を意図したものである。

今回われわれが使用したダイアライザー（東レ 社製 BK-2.1）は有効面積が $2.1 \mathrm{~m}^{2}$ であり，中分 子量物質の除去に優れているものである。筋保 護液は $\mathrm{K}$ 濃度 $20 \mathrm{mEq} / l$ のものを使用し, $10 〜 15$ $\mathrm{ml} / \mathrm{kg}$ を初回注入量として以降約 30 分毎に 5〜 $10 \mathrm{ml} / \mathrm{kg}$ を追加注入した。術後の血液浄化法 は全例で第 1 病日より HD を施行し, 抗凝固薬に はメシル酸ガベキサート (以下 FOY) またはメシ ル酸ナファムスタット（以下 FUT）を使用した。 術後数日間の HD は 100 200 ml/分の流量で開 始し, $2 \sim 5$ 時間で除水量 $1,000 \sim 1,500 \mathrm{ml}$ を目標 に行った。

\section{結＼cjkstart果}

手術直前の血清尿素窒素 (以下 BUN), クレア チン (以下 $\mathrm{Cr}$ ), 血清 $\mathrm{K}$ の值はそれぞれ $35.3 \pm$ $10.1 \mathrm{mg} / \mathrm{dl}, 7.6 \pm 1.1 \mathrm{mg} / \mathrm{dl}, 4.6 \pm 1.0 \mathrm{mEq} / l$ と なり，また術前体重もほぼ dry weightに近い状態 であった。術前の HD 中に狭心症を認めた症例は なかった。入院時のへモグロビン濃度（以下 $\mathrm{Hb}$ ) は $9.8 \pm 1.7 \mathrm{~g} / \mathrm{dl}$ であり, 術前に輸血を行った症 例はなかった。入院後より CAPD を導入し HD に代えて管理した 1 例は十分な除水量が得られず 心不全，肺水腫を起こしたため ECUM (extracorporeal ultrafiltration method）を施行し，HD と CAPDの両者にて管理した（表 1 ).

表 1 対象症例の透析療法

\begin{tabular}{cccccccc}
\hline Case & Age \&sex & $\begin{array}{c}\text { Extent of } \\
\text { conary disease }\end{array}$ & $\begin{array}{c}\text { Etiology of } \\
\text { nephropathy }\end{array}$ & $\begin{array}{c}\text { Dialysis } \\
\text { mode }\end{array}$ & $\begin{array}{c}\text { Dialysis } \\
\text { duration }\end{array}$ & $\begin{array}{c}\text { Prior } \\
\text { cardiac failure }\end{array}$ & Outcome \\
\hline 1 & $48 \mathrm{M}$ & 3 vessels & CGN & HD & $10 \mathrm{y}$ & - & alive \\
2 & $56 \mathrm{M}$ & 3 vessels & $\begin{array}{c}\text { Hyper- } \\
\text { tension }\end{array}$ & HD & $4 \mathrm{y}$ & - & alive \\
& & & & & & \\
3 & $58 \mathrm{M}$ & 2 vessels & Diabetes & HD & $3 \mathrm{y}$ & + & alive \\
& & & & CAPD & & & \\
4 & $50 \mathrm{M}$ & 3 vessels & CGN & HD & $6 \mathrm{y}$ & - & alive \\
5 & $53 \mathrm{M}$ & Left main & CGN & HD & $9 \mathrm{y}$ & - & alive \\
6 & $48 \mathrm{M}$ & 3 vessels & CGN & HD & $6 \mathrm{y}$ & - & alive \\
7 & $57 \mathrm{M}$ & 2 vessels & Diabetes & HD & $10 \mathrm{~m}$ & - & alive \\
\hline
\end{tabular}

HD : hemodialysis, CAPD : continuous ambulatory peritoneal dialysis, ECUM : extracorporeal ultrafiltration method, CGN : chronic glomerulo nephritis. 
冠動脈再建術は平均バイバス本数 $2.9 \pm 0.7$ 本, 体外循環時間 $170 \pm 13$ 分, 大動脈遮断時間 $85 \pm 21$ 分であった。人工心肺の回路内充填液量は $2,100 \pm 173 \mathrm{ml}$, 心筋保護液の使用量は $1,828 \pm$ $621 \mathrm{ml}$, 回路内への輸血量は $1,270 \pm 372 \mathrm{ml}$ であ った。体外循環中に電解質の調節のために用いた 置換液量は $12,952 \pm 3,972 \mathrm{ml}, \mathrm{HF} に よ る$ 濾過量 は $18,300 \pm 5,628 \mathrm{ml}$ であり, 体外循環中の除水量 は $5,348 \pm 2,089 \mathrm{ml}$ となった（図 1 ）。

この結果, 術前の $\mathrm{Ht}$ の平均值が $30.7 \pm 5.2 \%$ であるのに対し, 体外循環中の最低が $18.5 \pm$ $2.4 \%$, 体外循環終了時が $29.7 \pm 1.3 \%$ であった。 $\mathrm{HF}$ を使用した体外循環前後の BUN, $\mathrm{Cr}, \mathrm{K}$ の值 はBUNがそれぞれ $35.3 \pm 10.1 \mathrm{mg} / \mathrm{dl}, 21.8 \pm$ $6.0 \mathrm{mg} / \mathrm{dl}, \mathrm{Cr}$ がそれぞれ7.6土1.1mg/dl, $4.6 \pm$ $1.2 \mathrm{mg} / \mathrm{dl}$, 血清K值がそれぞれ $4.4 \pm 0.5 \mathrm{mEq} /$ $l, 4.3 \pm 0.5 \mathrm{mEq} / l$ であったが, 症例 1 では体外 循環終了時の血清 $\mathrm{K}$ 值が $3.2 \mathrm{mEq} / l$ であり, 心 室性不整脈の発生を認めた（図 2 ).

第 3 病日までの BUN, Cr, K の推移を図 3 に示 した。全例術後第 1 病日より HD を開始し, 術後 第 3 病日までの間に 2 回以上施行した. HD 施行 中に血行動態の変化を認めたものは 2 例であっ た. 1 例は第 1 病日の HD 開始後, 収縮期血圧が $90 \mathrm{mmHg}$ から $70 \mathrm{mmHg}$ へと低下した。この間, 自覚症状は認めず HD 終了時には収縮期血圧も $90 \mathrm{mmHg}$ に回復した。1 1 例は第 1 病日に気管内 チューブ抜管 2 時間後より HD を開始した症例 である。抜管により収縮期血圧が $160 \mathrm{mmHg}$ より $100 \mathrm{mmHg}$ まで低下した後, HD を開始したとこ ろ,一時的に $50 \mathrm{mmHg}$ まで血圧が低下した。この

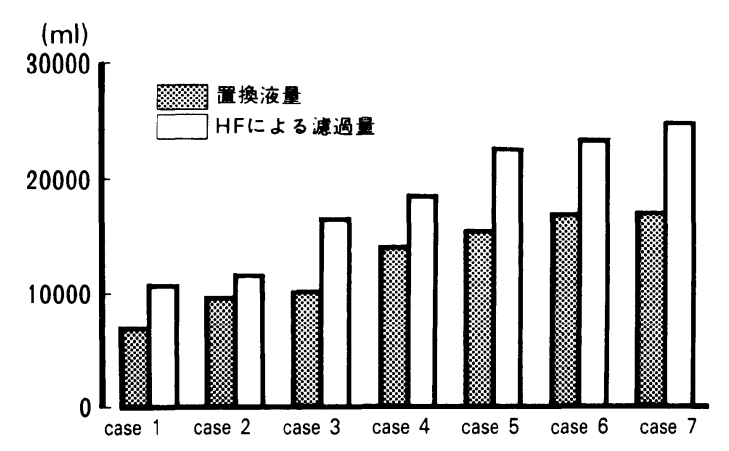

図 1 体外循環中の水分負荷と限外濾過量
時点でドブタミンを $3 \mu \mathrm{g} / \mathrm{kg} / \mathrm{min}$ で開始し, 濃厚 赤血球液と $5 \%$ アルブミン製剂の輸血および輸液

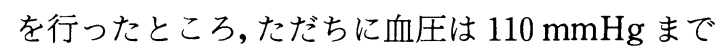
回復した.ドレーンからの排液量は 12 時間までが $460 \pm 207 \mathrm{ml}$, ドレーン抜去時までの総排液量は $842 \pm 350 \mathrm{ml}$ であり, 特に HDによって出血量が 増加するような傾向は認められなかった。術後合 併症として, 症例 $1,3,6$, で一過性の心房細 動や心膜切開後症候群を認めた. 症例 4 では術後 第 14 病日に十二指腸潰瘍を発症したが抗潰瘍剤 の投与により治癒した. 症例 2 は術後第 1 病日の
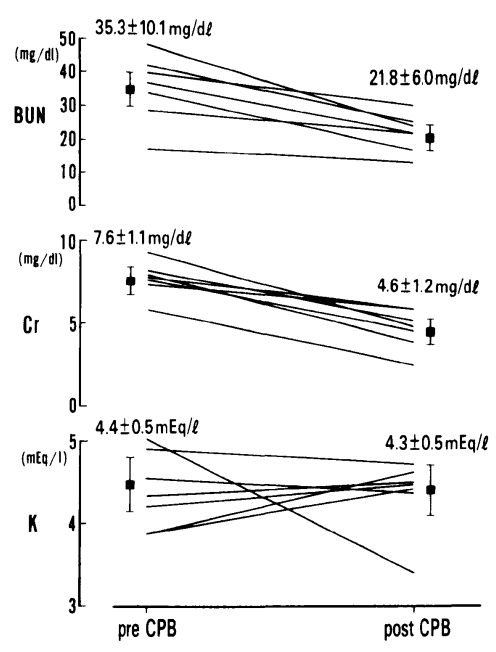

図 2 体外循環前後での $\mathrm{BUN}, \mathrm{Cr}, \mathrm{K}$ の変化
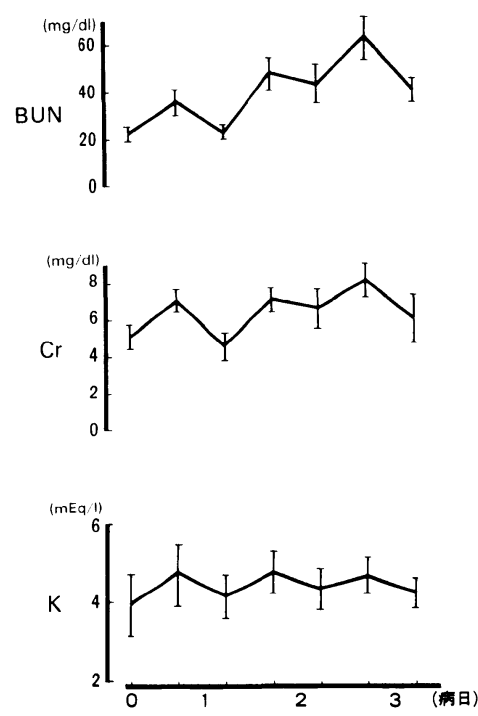

図 3 術後早期の $\mathrm{BUN}, \mathrm{Cr}, \mathrm{K}$ の変化 
$\mathrm{HD}$ 開始時より調節困難な高血圧（収縮期圧 180〜200 mmHg) が持続した. また, 術後第 6 病 日に心タンポナーデとなり再開胸術を施行した。 術中所見では，心囊液は血性ではなく獎液性であ った。この症例は代謝性脳症と遷延する低酸素血 症のため, 術後 22 日間 ICU に滞在した。症例 5 , 7 では術後合併症は認められなかった。術後の ICU 滑在日数は，再開胸術を施行した 1 例を除く 6 例は 4〜 5 日間であった. 全例週 3 回の血液透析 を再開し退院した。

\section{考察}

現在行われている冠動脈再建術中の水分量およ び電解質の調節方法は体外循環回路に組み込むも のとして, HD, ECUM, HF がある ${ }^{1,2)}$. 体外循環 中の HD は体外循環回路にダイアライザーを組 み込み，これに高流量の血液を流すことにより， 2〜3 時間という限られた体外循環時間内に透析 効率を上げようとするものである ${ }^{3 \sim 6)}$. 体外循環中 に ECUM による除水のみを行う方法と比較する と電解質の調節という点では優れている.しかし, この方法も術中の心筋保護液などの電解質負荷に 対しては十分ではなく, 注入された心筋保護液を 冠静脈より吸引儿体外循環回路外に廃棄するなど の手段7)をとる必要があり, 手技が煩雑である。体 外循環中の ECUM は HD に比べ簡便であるが, 電解質の調節は除水に伴って行われるものであ り, 大量の電解質の除去を行えば循環血液量も減 少する結果となる．電解質の調節を第一義的に考 えるのであれば，体外循環中の電解質液の負荷を 前提とした HF が合理的であり, uremic toxinの 除去という $\mathrm{HD}$ と同様の効果も期待できる.

われわれの行っている術中 HF は ECUM と異 なり, 限られた体外循環時間内でも通常の HD と ほぼ同等の効果が得られ，希釈率の調節も簡便で ある。筋保護液などの電解質負荷に対しても十 分な電解質の除去が可能で, 慢性透析患者以外の 冠動脈再建術とほぼ同様の手順で手術が行える. しかし, 症例 1 のように体外循環中の $\mathrm{HF}$ による 過剰な $\mathrm{K}$ の洗出しは，むしろ術後の低 $\mathrm{K}$ 血症を 招来する可能があり，この点で注意が必要である。 術後の血液浄化法は現在 PD を行う施設 ${ }^{8 \sim 13)}$ と
HD を行う施設に分れるようである ${ }^{14)}$. HD は PD より透析効率がよくタンパク漏失も問題とならな いが15 17), 血行動態に対する影響が大きく，抗凝 固薬使用による術後出血の危険性もある。一方, $\mathrm{PD}$ はD と比較して血行動態に対する影響が少 ないことが最大の利点である．血行動態の不安定 な症例では PDの選択が有利とも思われるが, 腹 膜血流の低下による透析効率の低下も予想され る. また術後の透析の開始時期については, 出血 や血行動態の安定といつた面からはできるだけ遅 らせることが望ましい. 今回の 7 症例は全例術後 第 1 病日に HD が施行された。体外循環中に HF を施行することにより，術当日に透析を必要とす るような症例は経験されなかった。 2 例で HD 中 の血圧低下を認めたが, 膠質液の輸液とカテコラ ミンの増量により速やかに血行動態は安定した。 また，透析時の抗凝固薬としてはFOY，FUT を 使用した結果 ${ }^{18,19)}$, 出血量の増加を認めた症例は なかった。

このほか術前管理が重要であることはいうまで もない.ことに術前の集約的血液透析は電解質の 調節, uremic toxin の除去, 体内水分量の調節に 有効である．また貧血を改善してから手術に望む べきであるとする考えもあるが，血液希釈率自体 は限外濾過による除水と回路内輸血により調節さ れるため, 術前の狭心症が貧血により増悪してい るような所見がなければ，必ずしも術前輸血は必 要ないと考える。

\section{結＼cjkstart論}

7 例の慢性透析患者の冠動脈再建術において, 体外循環中の HF により水分・電解質管理を試み た. 1 例では，むしろ術後の低 $\mathrm{K}$ 血症を認めたが， 術中から術後にかけて水分バランス・電解質は適 正に保たれ，全例第 1 病日まで術後の初回透析を 持ち越すことができた。術後経過は通常の冠動脈 再建術と比較しても何ら遜色のないものと思わ れ, 全例が術前と同様の透析方法に移行し退院し た. 以上のように HF は簡便性や効率などの点か らも優れた術中血液浄化法と考える。 


\section{文献}

1）後藤 武, 松本佑志, 土屋和彦ほか: 冠動脈バイ パス術中血液透析の経験一腎機能障害を有する 切迫心筋梗塞の 1 治験例一. 胸部外科 $38: 890$ 894, 1985.

2）幕内晴朗, 布施勝生, 小西敏雄ほか：PTCA 後緊 急 A-C バイパス術を行った血液透析患者の 1 治 験例. 日胸外会誌 33：1260-1266, 1985.

3）小泉誠二, 浜田幸男, 竹岸亮善ほか：急性腎不全 合併症例に対する血液透析を併用した心肺バイ パスの経験. 胸部外科 $36: 915-918,1983$.

4）須田昭夫, 東間 紘, 太田和夫ほか：血液透析患 者に打ける心内膜炎の 2 症例一 2 弁置換を行っ た 1 例を含めて一. 外科 $37: 317-321,1975$.

5) Soffer, O., MacDonell, R.G., Jr., Finlayson, D. C. et al. : Intraoperative hemodialysis during cardiopulmonary bypass in chronic renal failure. J. Thorac. Cardiovasc. Surg. 77 : 789-791, 1979.

6）飯田 司, 若山茂春, 神 敏郎ほか：慢性透析患 者に対する開心術の麻酔経験. 麻酔 30：624-629, 1981.

7) Kopman, E. A. : Scavenging of potassium cardioplegic solution to privent hyperkalemia in hemodialysis-dependent patients. Anesth. Analg. 62 : 780-782, 1983.

8) Crawford, F. A., Jr., Selby, J. H., Jr., Bower, J. D. et al.: Coronary revascularization in patients maintained on chronic hemodialysis. Circulation 55: 684-687, 1977.

9) Zawada, E. T., Jr., Stinson, J. B. and Done, G. :
New perspectives on coronary artery disease in hemodialysis patients. South. Med. J. 75 : 694696, 1982.

10）笹栗志朗, 安達秀雄, 漆久保潔ほか：血液透析中 患者の開心術の 1 治験例. 胸部外科 $34: 36-40$, 1981.

11）倉橋真人，杉村修一郎，小沢勝男ほか：慢性腎不 全患者に対する A-C バイパス術の 1 例. 日外会 誌 88：1031-1035, 1987.

12）竹村隆広, 遠藤真弘, 秋山一也ほか：持続携帯式 腹膜透析 (CAPD) 症例に合併した切迫梗塞の 2 手術治験例. 胸部外科 40:297-302, 1987.

13）高木 勇, 川副浩平，小坂井嘉夫ほか：透析患者 に対する開心術の検討。日胸外会誌 35：17121718, 1987.

14）浜田慎二, 浅原広澄，多川斉：透析患者におけ る冠動脈バイパス手術の麻酔経験. 臨床麻酔 9 : 311-316, 1985.

15）野尻明弘, 勝星弘忠: 血液透析か腹膜透析か. ICU と CCU 5: 873, 1981.

16）太田和夫：透析療法とその周辺知識. 南江堂, 東 京, 1979 .

17）飯田喜俊, 佐谷 誠, 白井大録：標準透析療法. p. 140. 中外医学社, 東京, 1981.

18）迫 裕孝, 中根佳宏, 沖野功次ほか：FUT-175を 使用した腎移植後血液透析. 移植 $22: 110-114$, 1986.

19）落合陽治, 戸梶昭博, 杉本清治ほか：急性腎不全 の血液浄化法における FUT-175 による抗凝固法 の検討. ICU と CCU 12: 37-41, 1988. 